METALLURGY AND FOUNDRY ENGINEERING - Vol. 36, 2010, No. 2

Jan Sińczak*, Aneta Łukaszek-Sołek**, Sylwia Bednarek**, Paweł Chyła***

\title{
THE FORGING PROCESS \\ OF AIRCRAFT ENGINES TURBINE BLADES
}

\section{INTRODUCTION}

Turbine compressor blade in aircraft engine works in severe conditions, i.e. under large temperature gradient and high mechanical loads. It must be characterized by high safety factor during operation life and fulfill correctness of shape in order to assure the requirements of engine efficiency.

Basic factors which guarantee the required operating properties of blades are shape and high precision of dimensions and also proper material used for production. To check possibilities to fulfill these requirements numerical modelling of forging processes is used. It allows to precisely investigate a problem and remove obstacles which can appear in course of working out technology without computer assistance [1]. An example of blades which are working in gas engine are shown in Figure 1.

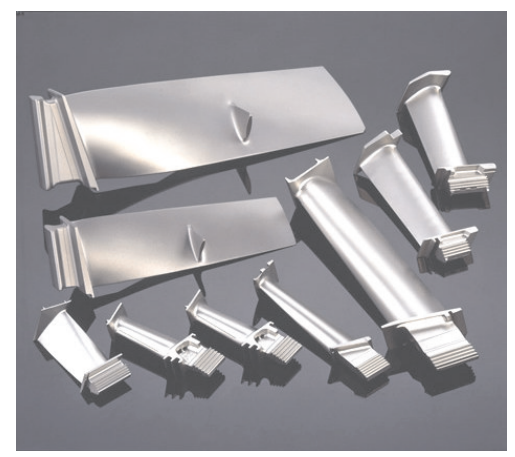

Fig. 1. An example of blades working in gas turbine [1]

* Prof., Ph.D., D.Sc., ** Ph.D., *** M.Sc.: Faculty of Metals Engineering and Industrial Computer Science, AGH University of Science and Technology, Kraków, Poland; e-mail: pchyla@metal.agh.edu.pl 
The number of blades in modern aircraft engines is counted in hundreds of pieces, and simultaneously the blades are responsible for correct running of the engine. Failure of even one blade could cause engine stoppage and/or its serious damage. In each engine many kinds of blades with miscellaneous shapes are working. They fulfill different roles and they run a risk of different working factors. Therefore these are manufactured with different methods with use of various materials. In Figure 2 a scheme of engine and distribution of temperature and pressure on engine section is shown. The particular zones where the blades are working were marked $[2,3]$.

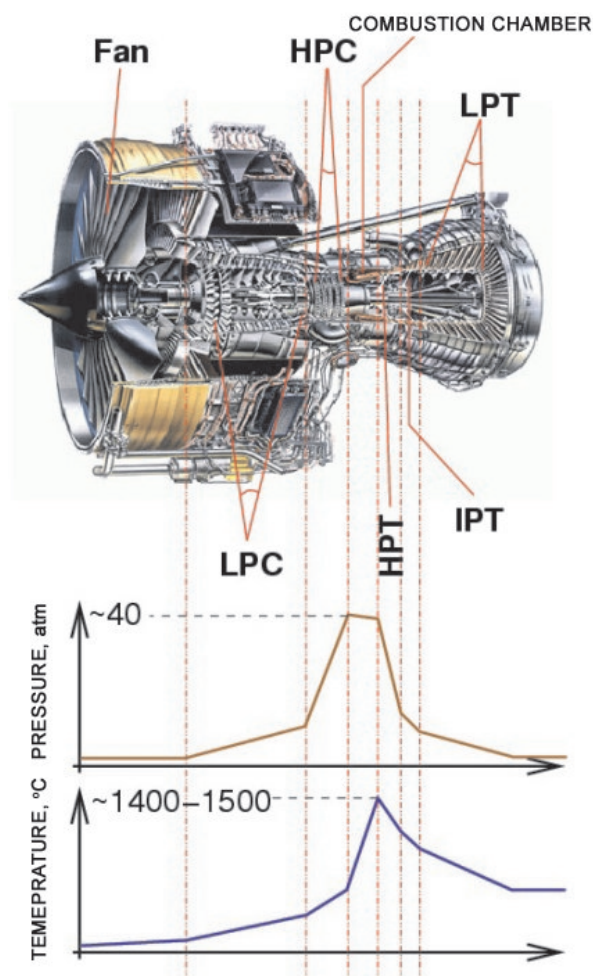

Fig. 2. Scheme of Trent engine of Rolls-Royce company and diagrams of pressure and temperature on section of driver unit [1]: LPC - low-pressure compressor, HPC - high-pressure compressor, $L P T$ - low-pressure turbine, IPT - medium pressure turbine, HPT-high-pressure turbine

Only the nickel-base superalloys fulfill extreme working conditions under which turbine elements are operating. Superalloys microstructure development in turbine blades was directed mainly on the increase of creep resistance. The least creep resistant are policrystal blades. The structure of blades with elongated grains in the direction of load increases creep resistance but does not guarantee suitable life. The most desirable are monocrystal blades, which guarantee even quadruple length of working time. Manufacturing monocrystal blades is very expensive and requires the use of advanced operations, i.e. very slow cooling $[4,5]$. In Figure 3 direction of structure development in blades is shown. 
a)

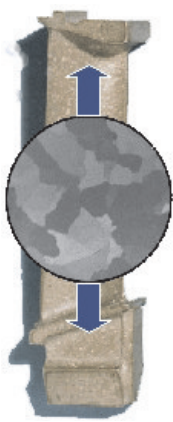

b)

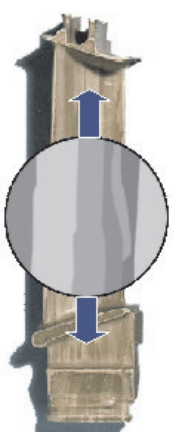

c)

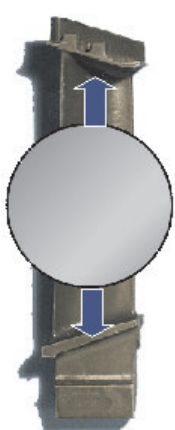

Fig. 3. Structure development direction in blades [4]: a) policrystal blade; b) policrystal blade with elongated grains; c) monocrystal blade

\section{BOUNDARY CONDITIONS OF NUMERICAL CALCULATIONS}

Because of process complexity and material costs the forging process of turbine blades was considered by using QForm3D to simulate the analyzed process. Nowadays in aircraft industry tests are carried out to bring in isothermal conditions in forging technology. Because of this various variants of tools temperature were analysed.

Geometrical models of tools and stock were generated by using SolidWorks program, on the basis of blade model (Fig. 4). The shape of the analyzed blade was based on real model of blade produced by American company Stork H\&E Turbo Blading Inc [6].

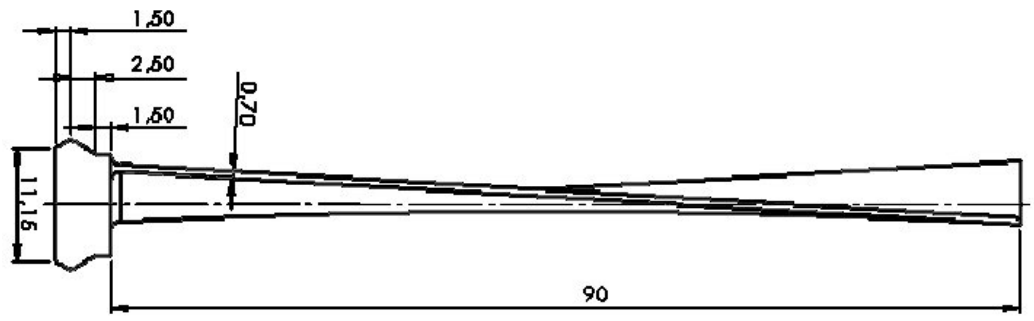

Fig. 4. Model of blade's forging [7]

In simulations two variants of stock were accepted. Both are characterized by shape near to forging profile in parting plane. First stock variant (Fig. 5a) was elaborated on the basis of perfect preform. It represents solid of revolution which has cross-sections equal to sum of cross-sections of forging and flash. Second variant isn't a solid of revolution. It has rectangle in its cross-section with dimensions given in Figure 5b. During perfect preform shape work out the stock volume was matched to guarantee precise impression fulfilling, and also to give an answer on how tools temperature influences forging process characteristic. 
a)

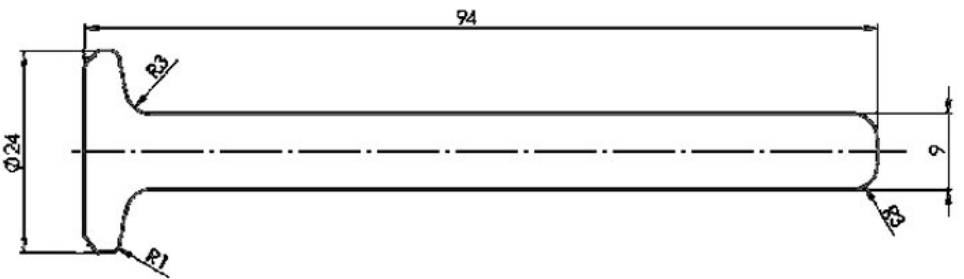

b)

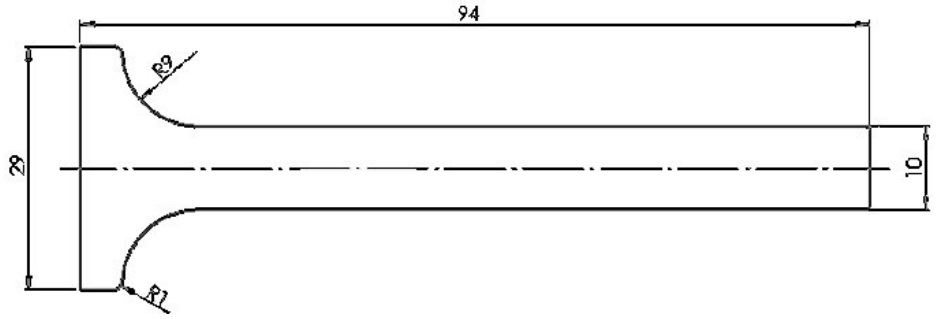

Fig. 5. Stock's dimensions: a) circular in head zone; b) flate in head zone [7]

Simulations were carried out for three-dimensional state of strain. The stock temperature was accepted as $980{ }^{\circ} \mathrm{C}$. Velocity of cross-bar was equal to $10 \mathrm{~mm} / \mathrm{s}$. Tools temperature was accepted as $500{ }^{\circ} \mathrm{C}$ and $700{ }^{\circ} \mathrm{C}$ respectively. For isothermal forging the joint temperature of stock, tools and environment amounted to $980{ }^{\circ} \mathrm{C}$. Friction factor between metal and tools equaled 0.5 .

\section{ANALISYS OF SIMULATION RESULTS}

Both stock variants in isothermal conditions were compared. After preliminary analysis of simulation results it was found that the conditions were considerably better in case of forging from circular head stock (Fig. 5a). During forging from the stock with flat head (Fig. 5b) laps in lock zone on both blade sides occurred (Fig. 6b), while when forging from the stock number 1 laps appeared only in flash (Fig. 6a), which is insignificant from technological point of view.

a)

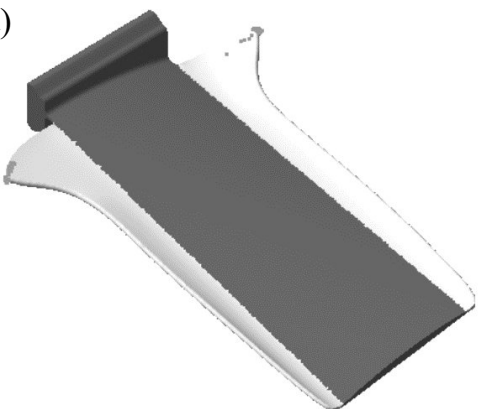

b)

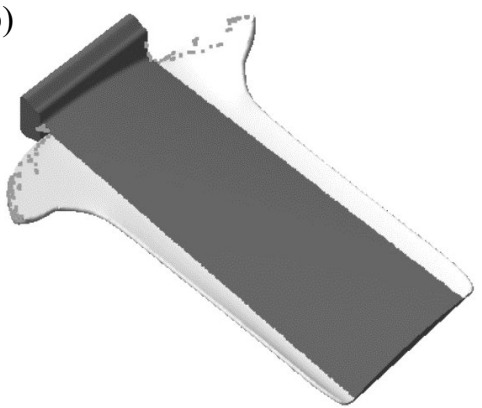

Fig. 6. Blade after isothermal forging: a) forging from the stock with circular head; b) forging from the stock with flat head 
Because of the laps forming in blade's lock forged from the stock with flat head further analysis was carried out for the stock with circular head.

\subsection{Effective strain distribution}

When analysing effective strain distribution (Fig. 7) similar values in analogical parts on blade surface could be seen. Higher values occur in lateral zones of blade, in places where material goes into a flash. Maximal effective strain amount 7 occurred in case of forging with tools heated to $700{ }^{\circ} \mathrm{C}$. Isothermal forging does not contribute to changes in described parameter. The minimal values occur at the blade's bottom. Probably it is the result of dies contact with the material right from the beginning of the process and the occurrence of lower temperature in this area in comparison to rest of the blade.
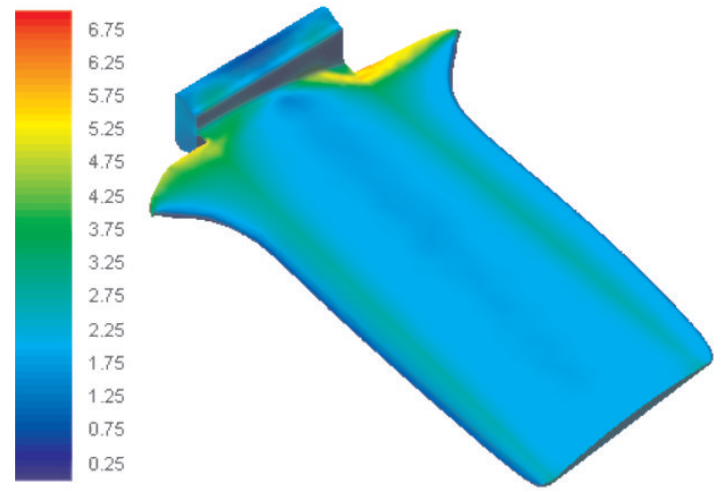

Fig. 7. Effective strain distribution in blade's forging

\subsection{Mean stress distribution}

In Figure 8 mean stress distribution in blade forging is shown. On blade's surface it amounts from $-1250 \mathrm{MPa}$ in flash area to $-4250 \mathrm{MPa}$ in central part for forgings formed with assumption of various tools temperature. During isothermal forging considerably lower mean stress values in analogical areas $(-700 \div-2000 \mathrm{MPa})$ has been noticed. Maximal mean stress (compressive) values are concentrated at blade's bottom. Mean stress violently increases in the area of passage from lock to blade. Because of that in this zone there will occur the first signs of dies wear.

\subsection{Load of forging process for various forming variants}

For each forging process variant obtained load values are presented in Figure 9. Considerable rise of loads at final stage of impression fulfilling is observed. In this phase of process flash is formed. Isothermal forging allows to considerably decrease loads at last stage of forming process. It is about $80 \%$ lower than loads in case of forging with the lowest tools temperature and about $50 \%$ lower than in the other case. 


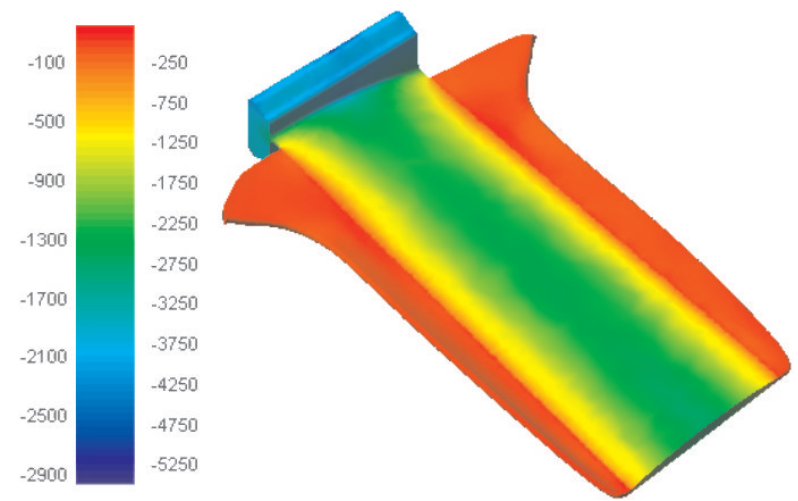

Fig. 8. Mean stress distribution in blade's forging; legend: left scale for isothermal conditions, right scale-for tools temperature $500{ }^{\circ} \mathrm{C}$ and $700{ }^{\circ} \mathrm{C}$

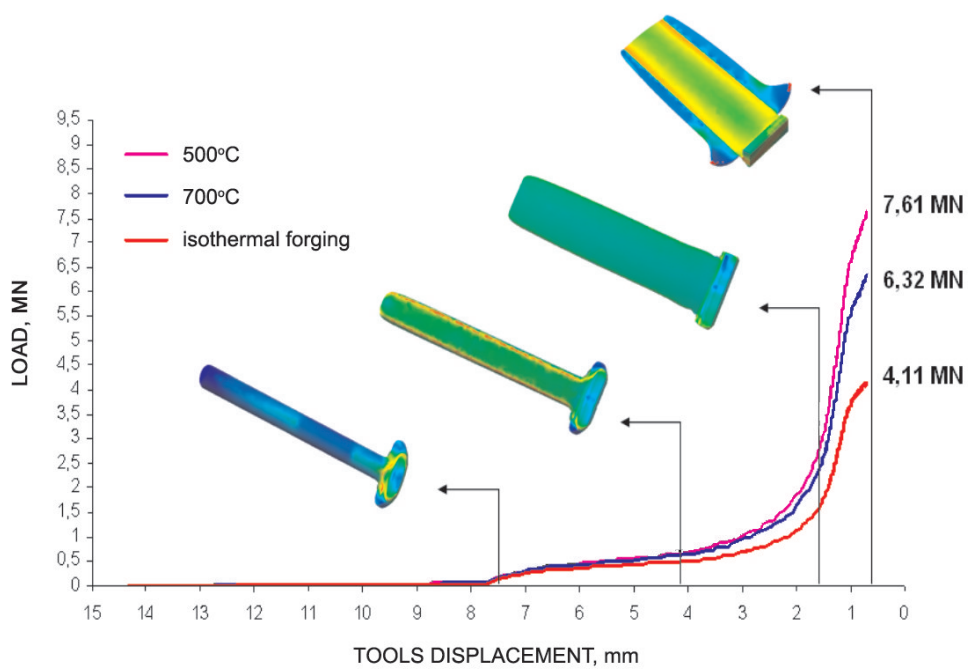

Fig. 9. Load dependence of tools displacement for various forging process variants

\section{SUMMARY AND CONCLUSIONS}

On the basis of carried out simulations the most favorable from technological point of view is forging under isothermal conditions. The most significant advantages of isothermal forging is elimination of temperature losses, considerably lower values of mean stress and half lower load needed for deformation. But to obtain proper conditions of isothermal forging special (expensive) technological solutions are required. Conventional forging allows to forge blades with use of poorer stock of machine tools, but for the sake of high stresses accumulation it forces producers to frequently change or even regenerate the tools. Furthermore, the formation of high temperature gradient in stock increases the risk of 
cracking and non-uniformity of deformation appearance. Because of that many blades can not pass quality tests and are disqualified from use. Moreover the optimization of stock shape is of great meaning. Ideal preform preparation considerably decreases the possibility of appearance of unfavourable effects during deformation. Thanks to that processing with larger deformations and forging of manufactures with more complicated shapes is possible.

To determine further development of forging application to producing blades of hightemperature creep resisting alloys it is necessary to investigate the problems of blades forging under isothermal conditions. Elaboration of blade's manufacturing methods from metallic or ceramic composites would probably revolutionize forging and foundry industry. Basing on literature and own researches [7] concerning of high-pressure compressor blade forging process characteristic it is possible to draw the following conclusions:

- Producing blades with forging methods is hard for the sake of high quotient of forging surface to volume. That is why the important element of technological process planning is adequate tools design and ideal preform shape selection.

- Conventional forging of blades is not very favourable for the sake of large heat losses and large temperature gradient formation on cross-section of forging. Higher tools temperature decreases unfavourable stresses and forging forces.

- Application of isothermal conditions in blades forging process in most favourable from technological point of view because it decreases forces needed to deformation twice, eliminates material temperature decrease and contributes to deformation uniformity.

- Forging of high-temperature creep resisting alloys is determined by high temperature gradient in stock and the tools, but the outcomes of applying forging under isothermal conditions are favourable enough to choose this particular technology.

- Numerical calculations indicate that manufacturing blades of high-temperature creep resisting alloys would be more profitable in case of precise forging under isothermal conditions.

- High-temperature creep resisting alloys are characterized by poor machinability therefore obtaining detail without machining allowance, with direct application of protective coating, would be quite an accomplishment.

\section{Acknowledgements}

Financial support of Structural Funds in the Operational Programme - Innovative Economy (IE OP) financed from the European Regional Development Fund - Project No WND-POIG.01.03.01-12-004/09 is gratefully acknowledged.

\section{REFERENCES}

[1] Utkin M.: Silnik turbinowy - jak to działa, Młody Technik, nr 7/2004

[2] Bucior J.: Kształtowanie niezawodności łopatek wirnika sprężarki lotniczych silników turbinowych metodami technologicznymi, Oficyna Wydawnicza Politechniki Rzeszowskiej, Rzeszów 1999 
[3] Dzierżanowski P., Kordziński W., Łyżwiński M.: Turbinowe silniki odrzutowe, Wydawnictwa Komunikacji i Łączności, Warszawa 1983

[4] http://www.doitpoms.ac.uk/tlplib/creep/other_metals.php?printable=1, $(10.10 .2010)$

[5] Biel M., Dubiel B., Czyrska-Filemnowicz A.: Monokrystaliczne nadstopy niklu na łopatki turbin gazowych, Hutnik-Wiadomości Hutnicze, $\mathrm{nr}$ 4/2002

[6] http://www.he-machinery.com/index.php?page=home, (10.10.2010)

[7] Kęa M.: Proces kucia łopatek turbin silników samolotowych, Praca dyplomowa AGH, Kraków 2009

\section{Received}

October 2010 